\title{
Change of calbindin D-28k protein expression in the mice hippocampus after lipopolysaccharide treatment
}

\author{
Tae-Ho CHUNG ${ }^{1)}$, Hee Soo $\mathrm{CHOI}^{2)}$ and Choong Hyun LEE ${ }^{2) *}$ \\ ${ }^{1)}$ Department of Animal Resources Science, Joongbu University, Chungnam 312-702, South Korea \\ ${ }^{2)}$ Department of Pharmacy, College of Pharmacy, Dankook University, Cheonan 330-714, South Korea
}

(Received 1 October 2014/Accepted 5 November 2014/Published online in J-STAGE 26 November 2014)

ABSTRACT. A previous study showed that $1 \mathrm{mg} / \mathrm{kg}$ lipopolysaccharide (LPS) treatment did not lead to the any neuronal death/degeneration in the mouse hippocampus. In the present study, we examined the time-dependent changes of calbindin D-28k (CB) protein expression in the mouse hippocampus after a systemic administration of $1 \mathrm{mg} / \mathrm{kg}$ LPS. CB immunoreactivity was markedly increased in pyramidal cells of the hippocampal CA1/2 regions and in granule cells of the dentate gyrus from $3 \mathrm{hr}$ to $48 \mathrm{hr}$ after LPS treatment. At this point in time, CB protein level was also significantly increased in the mouse hippocampus. Thereafter, CB protein expression was decreased at $96 \mathrm{hr}$ after LPS treatment. These results indicate that changes of CB protein expression may be associated with no neuronal death in the model of neuroinflammation with systemic administration of $1 \mathrm{mg} / \mathrm{kg}$ LPS.

KEY WORDS: calbindin, hippocampus, lipopolysaccharide

doi: 10.1292/jvms.14-0509; J. Vet. Med. Sci. 77(3): 349-352, 2015

Calcium binding proteins, which act as calcium buffer, control the intracellular calcium homeostasis and cellular activity $[3,9]$. Among the calcium binding proteins, calbindin D-28k (CB) binds to calcium ion with a fast association rate $[4,18]$. In the brain, neuronal $\mathrm{CB}$ is thought to regulate intracellular response against various stimuli and provide neuroprotection against calcium-mediated neurotoxicity $[2,17]$. In addition, CB-containing neurons play roles in memory, learning and long-term potentiation in the hippocampus [15].

Lipopolysaccharide (LPS), an endotoxin from gram-negative bacteria, leads to a strong response from normal animal immune system $[16,24]$. LPS has been commonly used as a reagent for a model of systemic inflammatory response induced by infections, and systemic LPS treatment leads to neuroinflammation with neuroanatomical and neurochemical changes in some regions of the brain $[8,13]$. Among the brain regions, the hippocampus is one of the brain regions most sensitive to LPS [6, 7].

Many previous studies have focused on effects of LPS on neuronal degeneration and immune response in various regions of the brain [19-21]. In addition, our previous studies showed that systemic administration of $1 \mathrm{mg} / \mathrm{kg}$ LPS led to microglial activation without any neuronal damage as well as changes of DNA repair ability in the mouse hippocampus $[6,11]$. However, there is no study on LPS-induced changes of $\mathrm{CB}$ protein expression in the hippocampus. Therefore, in

* Correspondence to: Lee, C. H., Department of Pharmacy, College of Pharmacy, Dankook University, Cheonan 330-714, South Korea. e-mail: anaphy@dankook.ac.kr

(C)2015 The Japanese Society of Veterinary Science

This is an open-access article distributed under the terms of the Creative Commons Attribution Non-Commercial No Derivatives (by-nc-nd) License $<$ http://creativecommons.org/licenses/by-nc-nd/3.0/>. the present study, we examined the time-dependent changes of $\mathrm{CB}$ immunoreactivity and protein level in the mouse hippocampus after a systemic administration of $1 \mathrm{mg} / \mathrm{kg}$ LPS.

Six-week-old male ICR mice were purchased from RaonBio Inc. (Yongin, South Korea). The animals were housed in a conventional state under adequate temperature $(23 \pm$ $3^{\circ} \mathrm{C}$ ) and relative humidity $(55 \pm 5 \%)$ control with a $12-\mathrm{hr}$ light/12-hr dark cycle and provided with free access to food and water. The procedures for animal handling and care adhered to guidelines that are in compliance with the current international laws and policies (Guide for the Care and Use of Laboratory Animals, The National Academies Press, 8th Ed., 2011) and were approved by the Institutional Animal Care and Use Committee at Dankook University. All of the experiments were conducted to minimize the number of animals used and the suffering caused by the procedures used in the present study.

LPS (Sigma, St. Louis, MO, U.S.A.) was dissolved in saline and administered intraperitoneally with $1.0 \mathrm{mg} / \mathrm{kg} /$ $10 \mathrm{ml}$ dose. The control animals were injected with the same volume of saline.

Mice ( $\mathrm{n}=5$ at each time point) were sacrificed at designated times (3, 6, 12, 24, 48 and $96 \mathrm{hr}$ after LPS treatment). For the histological analysis, animals were anesthetized with zoletil 50 (30 mg/kg, Virbac, Carros, France) and perfused transcardially with $0.1 \mathrm{M}$ phosphate-buffered saline (PBS, $\mathrm{pH}$ 7.4) followed by $4 \%$ paraformaldehyde in $0.1 \mathrm{M}$ phosphate-buffer ( $\mathrm{PB}, \mathrm{pH} 7.4)$. The brain tissues were removed, cryoprotected and serially sectioned on a cryostat (Leica, Wetzlar, Germany) into $30 \mu \mathrm{m}$ coronal sections, and they were then collected into 6-well plates containing PBS.

According to the method of our previous study $[6,11]$, immunohistochemical staining for $\mathrm{CB}$ was performed using rabbit anti-CB (1:200, Millipore, Temecula, CA, U.S.A.), biotinylated goat anti-rabbit IgG (1:200, Vector, Burlin- 
Table 1. Semi-quantifications of CB immunoreactivity in the mouse hippocampus after LPS treatment

\begin{tabular}{lccccccc}
\hline & \multicolumn{1}{c}{ Groups } \\
\cline { 2 - 8 } & Control & \multicolumn{7}{c}{ LPS treatment } \\
& & $3 \mathrm{hr}$ & $6 \mathrm{hr}$ & $12 \mathrm{hr}$ & $24 \mathrm{hr}$ & $48 \mathrm{hr}$ & $96 \mathrm{hr}$ \\
\hline Pyramidal cells of CA1/2 region & \pm & ++ & ++ & ++ & ++ & ++ & \pm \\
Granule cells of dentate gyrus & + & ++ & ++ & ++ & ++ & ++ & \pm \\
\hline
\end{tabular}

Immunoreactivity is scaled as,,- \pm+ or ++ , representing no staining, weakly positive, moderate or strong, respectively.

game, CA, U.S.A.) and streptavidin peroxidase complex (1:200, Vector). In order to establish the specificity of the immunostaining, a negative control test was carried out with pre-immune serum instead of primary antibody. The negative control resulted in the absence of immunoreactivity in any structures (data not shown).

Six sections with $120 \mu \mathrm{m}$ intervals per animal were selected to quantitatively analyze $\mathrm{CB}$ immunoreactivity. Digital images of the hippocampal subregions were captured with an AxioM2 light microscope (Carl Zeiss, Göttingen, Germany) equipped with a digital camera (Axiocam, Carl Zeiss) connected to a PC monitor. Semi-quantification of the immunostaining intensities in the pyramidal cells of the hippocampal CA1/2 region and in the granular cells of the dentate gyrus was evaluated with Image J 1.46 (National Institutes of Health, Bethesda, MD, U.S.A.). The mean intensity of immunostaining in each immunoreactive structure was measured by a $0-255$ gray scale system (white to dark signal corresponded from 255 to 0 ). Based on this approach, the level of immunoreactivity was scaled as,,- \pm+ or ++ , representing no staining (gray scale value: $\geq 200$ ), weakly positive (gray scale value: 150-199), moderate (gray scale value: 100-149) or strong (gray scale value: $\leq 99$ ), respectively.

To confirm change in CB levels in the hippocampus at designated times (3, 48 and $96 \mathrm{hr}$ after LPS treatment), animals at each time point $(n=5)$ were used for western blot analysis according to the method of our previous study $[6,11]$. In brief, after the hippocampus was homogenized and centrifuged, the supernatants were subjected to western blot analysis. Rabbit anti-CB (1:1,000, Millipore) or mouse anti- $\beta$-actin $(1: 5,000$, Sigma) was used as a primary antibody. The result of the western blot analysis was scanned, and densitometric analysis for the quantification of the bands was done using Image J 1.46, which was used to count relative optical density (ROD). CB level was normalized with $\beta$-actin level, used for internal control protein. A ratio of the ROD was calibrated as $\%$ with the control-group designated as $100 \%$.

Data are expressed as the mean \pm SEM. The data were evaluated by SPSS program and the means assessed using two-tailed Student $t$-test or one-way ANOVA test. Statistical significance was considered at $P<0.05$.

In the hippocampal CA1 and CA2 regions of the controlgroup, weak CB immunoreactivity was detected in pyramidal cells of the striatum pyramidale (Table 1, Fig. 1A). At $3 \mathrm{hr}$ after LPS treatment, CB immunoreactivity was markedly in- creased in the pyramidal neurons, and increased CB immunoreactivity was maintained until $48 \mathrm{hr}$ after LPS treatment (Table 1, Fig. 1B and 1C). Thereafter, CB immunoreactivity in pyramidal cells of the striatum pyramidale was decreased at $96 \mathrm{hr}$ after LPS treatment (Table 1, Fig. 1D).

In the CA3 region of the control-group, $\mathrm{CB}$ immunoreactivity was observed in the stratum lucidum, not in the stratum pyramidale (Fig. 1E). CB immunoreactivity in the stratum lucidum was also increased from $3 \mathrm{hr}$ to $48 \mathrm{hr}$ after LPS treatment (Fig. $1 \mathrm{~F}$ and $1 \mathrm{G}$ ). At $96 \mathrm{hr}$ after LPS treatment, $\mathrm{CB}$ immunoreactivity was distinctively decreased in the stratum lucidum (Fig. 1H).

In the dentate gyrus of the control-group, $\mathrm{CB}$ immunoreactivity was well observed in granule cells (Table 1, Fig. 1I). From $3 \mathrm{hr}$ to $48 \mathrm{hr}$ after LPS treatment, CB immunoreactivity in granule cells was markedly increased, compared to that in the control-group (Table 1, Fig. $1 \mathrm{~J}$ and $1 \mathrm{~K}$ ). Thereafter, CB immunoreactivity at $96 \mathrm{hr}$ after LPS treatment was apparently decreased, compared to that at $48 \mathrm{hr}$ after LPS treatment (Table 1, Fig. 1L).

Western blot analysis showed that the CB protein level was changed in the mouse hippocampus after LPS treatment, and the pattern of change of $\mathrm{CB}$ protein level was similar to that observed in the immunohistochemical data. $\mathrm{CB}$ protein levels were significantly increased at $3 \mathrm{hr}$ and $48 \mathrm{hr}$ after LPS treatment. At $96 \mathrm{hr}$ after LPS treatment, the CB protein level was similar to that in control-group (Fig. 2).

LPS leads to neuronal death by activations of microglia and astrocytes as well as by increase of oxidative stress and alteration of calcium homeostasis [12, 19-21, 25]. It was reported that PC12 neurons showed a significant intracellular calcium overload in response to $20 \mu \mathrm{g} / \mathrm{m} l$ of LPS for 48 $\mathrm{hr}$ and that nonselective cationic channel blockers inhibited LPS-induced neuronal death [19]. In addition, systemic LPS treatment induced cognitive impairment in mice [22, 23] and led to neuroinflammation, sickness and mild depressive-like behavior [5]. It has been also known that systemic inflammation induced by $10 \mathrm{mg} / \mathrm{kg}$ LPS treatment led to cellular apoptosis (15\% neurons and $85 \%$ glia) in the rat hippocampus [21]. Previously, we reported that $1 \mathrm{mg} / \mathrm{kg}$ LPS treatment did not lead to the neuronal death/degeneration in the pyramidal and granule cells of the mouse hippocampus [6], although DNA repair ability in the hippocampal pyramidal and granule cells was affected after $1 \mathrm{mg} / \mathrm{kg}$ LPS treatment [11]. Therefore, it has been thought that neuronal death after systemic LPS treatment is dependent on the dose of LPS. 

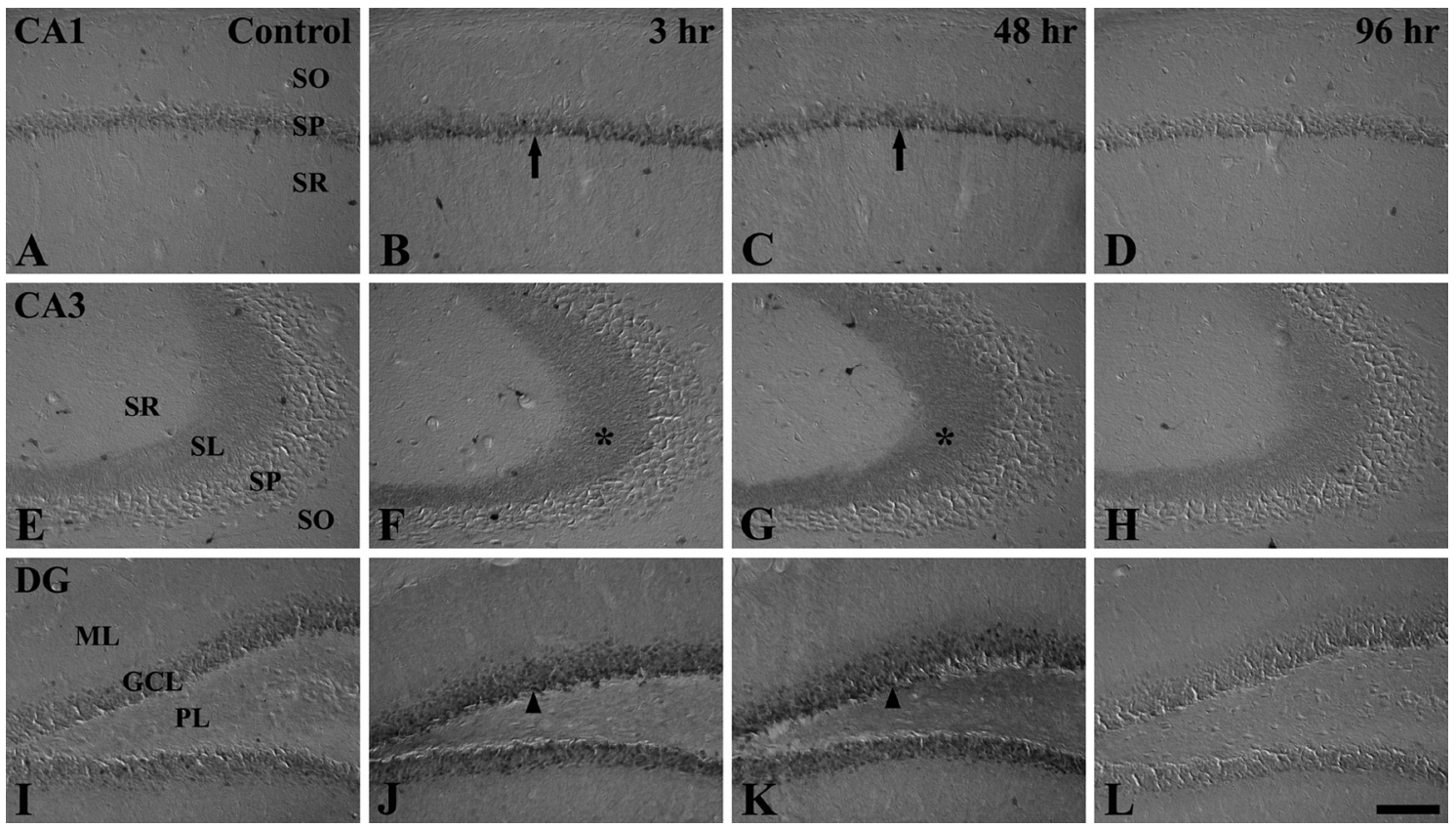

Fig. 1. Immunohistochemistry for $\mathrm{CB}$ in the $\mathrm{CA} 1$ region $(\mathrm{A}-\mathrm{D})$, the $\mathrm{CA} 3$ region $(\mathrm{E}-\mathrm{H})$ and the dentate gyrus $(\mathrm{I}-\mathrm{L})$ of the control- (A, E and I) and LPS-treated (B-D, F-H and J-L)-groups. From $3 \mathrm{hr}$ to $48 \mathrm{hr}$ after LPS treatment, CB immunoreactivity is markedly increased in the stratum pyramidale (SP, arrows) of the CA1 region, in the stratum lucidum (SL, asterisks) of the CA3 region and in the granule cell layer (GCL, arrowheads) of the dentate gyrus. SO; stratum oriens, SR; stratum radiatum, ML; molecular layer, PL; polymorphic layer. Scale Bar $=100 \mu \mathrm{m}$.

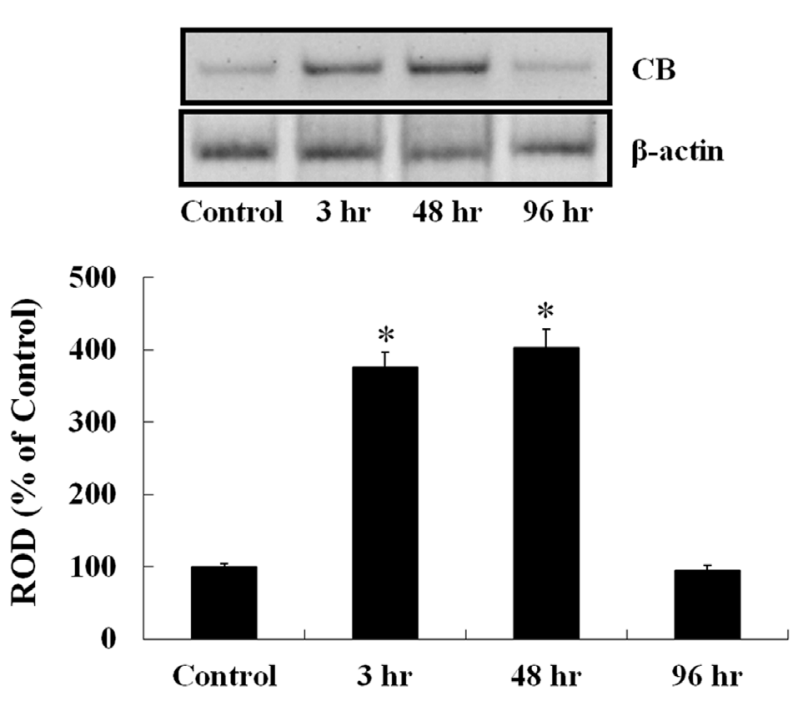

Fig. 2. Western blot analysis of $\mathrm{CB}$ in the mouse hippocampus of the control- and LPS-treated-groups. Relative optical density (ROD) as \% values of immunoblot band is also represented $(\mathrm{n}=5$, $* P<0.05$, significantly different from the control-group). The bars indicate the means \pm SEM.

In the present study, we examined the changes of $\mathrm{CB}$ protein expression in the hippocampal CA1-3 regions and dentate gyrus after systemic treatment with $1 \mathrm{mg} / \mathrm{kg}$ LPS. It was reported that $\mathrm{CB}$ immunoreactivity was found predomi- nantly in the pyramidal cells of the $\mathrm{CA} 1 / 2$ regions, not $\mathrm{CA} 3$ region, and in the granule cells of the dentate gyrus of the rat hippocampus [14]. We observed that the CB immunoreactivity in the pyramidal cells of the CA $1 / 2$ regions and in the granule cells of the dentate gyrus as well as the $\mathrm{CB}$ protein level in the hippocampus was markedly increased from $3 \mathrm{hr}$ to $48 \mathrm{hr}$ after LPS treatment. Although it is hard to exactly explain why CB protein expression was increased in the hippocampus after LPS treatment, it can be postulated that the increase of $\mathrm{CB}$ immunoreactivity in pyramidal and granule cells may be related to neuroprotection against LPS-induced neuronal death/degeneration in the mouse hippocampus, based on the results of the previous study [19]. In addition, we observed that $\mathrm{CB}$ immunoreactivity was increased in the stratum lucidum of the hippocampal CA3 region. It has been known that $\mathrm{CB}$ is closely associated with long-term potentiation, synaptic plasticity and memory functions $[1,10,14]$. Therefore, this result indicates that increase of CB immunoreactivity in the stratum lucidum may be related to the LPSinduced changes of hippocampal function, although we did not examine the changes of long-term potentiation, synaptic plasticity and memory functions after LPS treatment in the present study.

In conclusion, $\mathrm{CB}$ protein expression was apparently increased in the mouse hippocampus after systemic administration of $1 \mathrm{mg} / \mathrm{kg}$ LPS. These results indicate that changes in CB protein expression may be associated with no neuronal death in the model of neuroinflammation with systemic administration of $1 \mathrm{mg} / \mathrm{kg}$ LPS. 
ACKNOWLEDGMENT. The present research was conducted by the research fund of Dankook University in 2014 (122397).

\section{REFERENCES}

1. Abrahám, H., Veszpremi, B., Kravjak, A., Kovacs, K., Gomori, E. and Seress, L. 2009. Ontogeny of calbindin immunoreactivity in the human hippocampal formation with a special emphasis on granule cells of the dentate gyrus. Int. J. Dev. Neurosci. 27: 115-127. [Medline] [CrossRef]

2. Airaksinen, M. S., Thoenen, H. and Meyer, M. 1997. Vulnerability of midbrain dopaminergic neurons in calbindin-D28kdeficient mice: lack of evidence for a neuroprotective role of endogenous calbindin in MPTP-treated and weaver mice. Eur. J. Neurosci. 9: 120-127. [Medline] [CrossRef]

3. Baimbridge, K. G., Celio, M. R. and Rogers, J. H. 1992. Calcium-binding proteins in the nervous system. Trends Neurosci. 15: 303-308. [Medline] [CrossRef]

4. Berggård, T., Miron, S., Onnerfjord, P., Thulin, E., Akerfeldt, K. S., Enghild, J. J., Akke, M. and Linse, S. 2002. Calbindin D28k exhibits properties characteristic of a Ca2+ sensor. J. Biol. Chem. 277: 16662-16672. [Medline] [CrossRef]

5. Biesmans, S., Meert, T. F., Bouwknecht, J. A., Acton, P. D., Davoodi, N., De Haes, P., Kuijlaars, J., Langlois, X., Matthews, L. J., Ver Donck, L., Hellings, N. and Nuydens, R. 2013. Systemic immune activation leads to neuroinflammation and sickness behavior in mice. Mediators Inflamm. 2013: 271359. [Medline] [CrossRef]

6. Chung, D. W., Yoo, K. Y., Hwang, I. K., Kim, D. W., Chung, J. Y., Lee, C. H., Choi, J. H., Choi, S. Y., Youn, H. Y., Lee, I. S. and Won, M. H. 2010. Systemic administration of lipopolysaccharide induces cyclooxygenase-2 immunoreactivity in endothelium and increases microglia in the mouse hippocampus. Cell. Mol. Neurobiol. 30: 531-541. [Medline] [CrossRef]

7. Gluck, M. A. and Myers, C. E. 1997. Psychobiological models of hippocampal function in learning and memory. Annu. Rev. Psychol. 48: 481-514. [Medline] [CrossRef]

8. Guan, Z. and Fang, J. 2006. Peripheral immune activation by lipopolysaccharide decreases neurotrophins in the cortex and hippocampus in rats. Brain Behav. Immun. 20: 64-71. [Medline] [CrossRef]

9. Heizmann, C. W. 1993. Calcium signaling in the brain. Acta Neurobiol. Exp. (Warsz.) 53: 15-23. [Medline]

10. Jouvenceau, A., Potier, B., Battini, R., Ferrari, S., Dutar, P. and Billard, J. M. 1999. Glutamatergic synaptic responses and longterm potentiation are impaired in the CA1 hippocampal area of calbindin D(28k)-deficient mice. Synapse 33: 172-180. [Medline] [CrossRef]

11. Lee, H. Y., Park, J. H., Lee, C. H., Yan, B., Ahn, J. H., Lee, Y. J., Park, C. W., Cho, J. H., Choi, S. Y. and Won, M. H. 2012. Changes of ribosomal protein S3 immunoreactivity and its new expression in microglia in the mice hippocampus after lipopolysaccharide treatment. Cell. Mol. Neurobiol. 32: 577-586. [Medline] [CrossRef]

12. Li, B., Guo, Y. S., Sun, M. M., Dong, H., Wu, S. Y., Wu, D. X. and Li, C. Y. 2008. The NADPH oxidase is involved in lipopolysaccharide-mediated motor neuron injury. Brain Res. 1226: 199-208. [Medline] [CrossRef]
13. Linthorst, A. C., Flachskamm, C., Holsboer, F. and Reul, J. M. 1995. Intraperitoneal administration of bacterial endotoxin enhances noradrenergic neurotransmission in the rat preoptic area: relationship with body temperature and hypothalamic-pituitaryadrenocortical axis activity. Eur. J. Neurosci. 7: 2418-2430. [Medline] [CrossRef]

14. Lolova, I. and Davidoff, M. 1992. Age-related morphological and morphometrical changes in parvalbumin- and calbindinimmunoreactive neurons in the rat hippocampal formation. Mech. Ageing Dev. 66: 195-211. [Medline] [CrossRef]

15. Molinari, S., Battini, R., Ferrari, S., Pozzi, L., Killcross, A. S., Robbins, T. W., Jouvenceau, A., Billard, J. M., Dutar, P., Lamour, Y., Baker, W. A., Cox, H. and Emson, P. C. 1996. Deficits in memory and hippocampal long-term potentiation in mice with reduced calbindin D28K expression. Proc. Natl. Acad. Sci. U.S.A. 93: 8028-8033. [Medline] [CrossRef]

16. Morrison, D. C. and Ryan, J. L. 1979. Bacterial endotoxins and host immune responses. Adv. Immunol. 28: 293-450. [Medline] [CrossRef]

17. Nägerl, U. V., Mody, I., Jeub, M., Lie, A. A., Elger, C. E. and Beck, H. 2000. Surviving granule cells of the sclerotic human hippocampus have reduced $\mathrm{Ca}(2+)$ influx because of a loss of calbindin-D(28k) in temporal lobe epilepsy. J. Neurosci. 20: 1831-1836. [Medline]

18. Nägerl, U. V., Novo, D., Mody, I. and Vergara, J. L. 2000. Binding kinetics of calbindin-D(28k) determined by flash photolysis of caged $\mathrm{Ca}(2+)$. Biophys. J. 79: 3009-3018. [Medline] [CrossRef]

19. Nuñez-Villena, F., Becerra, A., Echeverria, C., Briceno, N., Porras, O., Armisen, R., Varela, D., Montorfano, I., Sarmiento, D. and Simon, F. 2011. Increased expression of the transient receptor potential melastatin 7 channel is critically involved in lipopolysaccharide-induced reactive oxygen species-mediated neuronal death. Antioxid. Redox Signal. 15: 2425-2438. [Medline] [CrossRef]

20. Qin, L., Wu, X., Block, M. L., Liu, Y., Breese, G. R., Hong, J. S., Knapp, D. J. and Crews, F. T. 2007. Systemic LPS causes chronic neuroinflammation and progressive neurodegeneration. Glia 55: 453-462. [Medline] [CrossRef]

21. Semmler, A., Okulla, T., Sastre, M., Dumitrescu-Ozimek, L. and Heneka, M. T. 2005. Systemic inflammation induces apoptosis with variable vulnerability of different brain regions. J. Chem. Neuroanat. 30: 144-157. [Medline] [CrossRef]

22. Shaw, K. N., Commins, S. and O'Mara, S. M. 2001. Lipopolysaccharide causes deficits in spatial learning in the watermaze but not in BDNF expression in the rat dentate gyrus. Behav. Brain Res. 124: 47-54. [Medline] [CrossRef]

23. Sparkman, N. L., Martin, L. A., Calvert, W. S. and Boehm, G. W. 2005. Effects of intraperitoneal lipopolysaccharide on Morris maze performance in year-old and 2-month-old female C57BL/6J mice. Behav. Brain Res. 159: 145-151. [Medline] [CrossRef]

24. Tough, D. F., Sun, S. and Sprent, J. 1997. T cell stimulation in vivo by lipopolysaccharide (LPS). J. Exp. Med. 185: 2089-2094. [Medline] [CrossRef]

25. Yeh, S. H., Hung, J. J., Gean, P. W. and Chang, W. C. 2008. Hypoxia-inducible factor-1alpha protects cultured cortical neurons from lipopolysaccharide-induced cell death via regulation of NR1 expression. J. Neurosci. 28: 14259-14270. [Medline] [CrossRef] 